\title{
A groundwater recharge perspective on locating tree plantations within low-rainfall catchments to limit water resource losses
}

\author{
J. F. Dean ${ }^{1,2, *}$, J. A. Webb ${ }^{1,2}$, G. E. Jacobsen ${ }^{3}$, R. Chisari ${ }^{3}$, and P. E. Dresel ${ }^{4}$ \\ ${ }^{1}$ Agricultural Sciences Department, La Trobe University, Bundoora, Victoria, Australia \\ ${ }^{2}$ National Centre for Groundwater Research and Training, Adelaide, Australia \\ ${ }^{3}$ Institute for Environmental Research, ANSTO, Sydney, Australia \\ ${ }^{4}$ Department of Environment and Primary Industries, Bendigo, Victoria, Australia \\ *now at: Biological and Environmental Sciences, University of Stirling, Scotland, UK
}

Correspondence to: J. F. Dean (joshua.dean@sitr.ac.uk)

Received: 8 July 2014 - Published in Hydrol. Earth Syst. Sci. Discuss.: 28 August 2014 Revised: 22 January 2015 - Accepted: 7 February 2015 - Published: 26 February 2015

\begin{abstract}
Despite the many studies that consider the impacts of plantation forestry on groundwater recharge, and others that explore the spatial heterogeneity of recharge in low-rainfall regions, there is little marriage of the two subjects in forestry management guidelines and legislation. Here we carry out an in-depth analysis of the impact of reforestation on groundwater recharge in a low-rainfall $(<700 \mathrm{~mm}$ annually), high-evapotranspiration paired catchment characterized by ephemeral streams. Water table fluctuation (WTF) estimates of modern recharge indicate that little groundwater recharge occurs along the topographic highs of the catchments (average $18 \mathrm{~mm} \mathrm{yr}^{-1}$ ); instead the steeper slopes in these areas direct runoff downslope to the lowland areas, where most recharge occurs (average $78 \mathrm{~mm} \mathrm{yr}^{-1}$ ). Recharge estimates using the chloride mass balance (CMB) method were corrected by replacing the rainfall input $\mathrm{Cl}^{-}$value with that for streamflow, because most recharge occurs from infiltration of runoff through the streambed and adjacent low gradient slopes. The calculated CMB recharge values (average $10 \mathrm{~mm} \mathrm{yr}^{-1}$ ) are lower than the WTF recharge values (average $47 \mathrm{~mm} \mathrm{yr}^{-1}$ ), because they are representative of groundwater that was mostly recharged prior to European land clearance (> BP 200 years). The tree plantation has caused a progressive drawdown in groundwater levels due to tree water use; the decline is less in the upland areas.

The results of this study show that spatial variations in recharge are important considerations for locating tree plantations. To conserve water resources for downstream users in low-rainfall, high-evapotranspiration regions, tree plant-
\end{abstract}

ing should be avoided in the dominant zone of recharge, i.e. the topographically low areas and along the drainage lines, and should be concentrated on the upper slopes, although this may negatively impact the economic viability of the plantation.

\section{Introduction}

Tree plantations are known to have the potential to reduce groundwater recharge and surface water flows (e.g. Bell et al., 1990; Benyon, 2002; Bosch and Hewlett, 1982; Jobbagy and Jackson, 2004; Scanlon et al., 2007; van Dijk et al., 2007), particularly in low-rainfall, high-evapotranspiration regions where the high transpiration demands of the trees make them a significant user in the water balance (e.g. Benyon et al., 2006; Fekeima et al., 2010; Jackson et al., 2005; Schofield, 1992). This is often regarded as a negative aspect of tree plantations, but may be a positive outcome if the aim of a particular forestry project is to reduce groundwater levels, e.g. to decrease groundwater salinization (discussed further below). Groundwater recharge in low-rainfall regions is also affected by a variety of other factors that cause substantial spatial variability - in particular topography, soil characteristics and geology (e.g. Delin et al., 2000; Scanlon et al., 2002; Schilling, 2009; Webb et al., 2008; Winter, 2001). However, the important conclusions made in the recharge studies have not been brought together with the results of tree plantation studies and directly applied to water 
resource management problems accompanying the establishment of tree plantations (Farley et al., 2005).

Since the earliest work on defining groundwater systems, recharge has been shown to be controlled predominantly by topography: the majority of groundwater recharge occurs at topographic highs, and discharge is mostly in topographic lows where the upward hydraulic gradient prevents recharge from occurring (Domenico and Schwartz, 1998; Schilling, 2009). However, in arid and semi-arid regions, recharge following rainfall events often occurs predominantly in local depressions and along ephemeral streams (diverging from early conceptual models), due to the focusing of overland flow in these areas. Water tables under ephemeral streams are generally below the streambed (except during extended rainfall events), and therefore upwards groundwater gradients do not occur most of the time. Infiltration beneath these areas may also be encouraged by the presence of preferential pathways, along which infiltrating water may more readily reach the water table (Delin et al., 2000; Scanlon et al, 2002; Schilling, 2009; Winter, 2001). In southeastern Australia in particular, it has been observed that recharge can vary significantly within catchments due to multiple modes of recharge (Cartwright et al., 2007).

Vegetation can significantly impact groundwater recharge due to transpiration and by intercepting rainfall and overland flow (Scanlon et al., 2002; Winter, 2001); changing land use can therefore affect recharge patterns. For example, land salinization has occurred in large parts of southeastern Australia due to the replacement of native forest by pasture and crops that use less water; this has led to increased recharge which raised water tables, causing saline groundwater to come to the land surface and discharge into surface water features (Allison et al., 1990; Bennetts et al., 2006, 2007). In contrast, afforestation of cleared farmland is likely to decrease recharge, due to the high rate of transpiration by the actively growing, closely planted trees, as well as the interception of overland flow and evaporation from the canopy (Benyon et al., 2006). In particular, the evergreen eucalyptus tree plantations commonly planted in southeastern Australia take up and transpire significantly more water than pasture, their canopy intercepts more rainfall and allows it to evaporate, and their roots reach greater depths than grasses, meaning they can extract water over a larger volume of the soil column (Bosch and Hewlett, 1982; Feikema et al., 2010; Hibbert, 1967). This recharge reduction is the reason why some studies have suggested using targeted tree plantations to reduce recharge in areas where there are high rates of saline groundwater discharge (e.g. Bennetts et al., 2007). Tree plantations also sequester carbon dioxide, prompting ongoing debate over the trade-off between increased water use by trees versus their increased carbon sequestration potential (Farley et al., 2005). As such, efforts over the past few decades in southeastern Australia to reforest land that was cleared in the late 1800s by European settlers (Schofield, 1992) are now causing difficulties for land managers trying to define sus- tainable action plans for surface water and groundwater (Dalhaus et al., 2008; Jackson et al., 2005; Nicholson et al., 2006).

A whole-catchment approach is key to managing groundwater recharge in the context of land use change (Cartwright et al., 2007). However, despite the evidence that recharge is often concentrated in topographic lows, groundwater management strategies in southeastern Australia typically operate on the assumption that recharge occurs primarily in the upper parts of catchments, particularly along the ridgelines. Current regulations for tree plantations in Australia focus on the percentage of a given catchment that can be forested, rather than what areas should be planted to maintain or intercept groundwater recharge, depending on the management application.

Here we present the findings from a paired catchment study in southwestern Victoria, Australia, where one catchment is planted with a tree plantation, and the adjacent catchment is covered with pasture. This approach largely removes the variables of climate, topography, soil and geology, with the only major difference between the two catchments being vegetation cover. Previous paired catchment studies on the impact of tree plantations tended to focus on surface water responses to afforestation, while groundwater has been somewhat neglected (Brown et al., 2005). In this study conceptual models of groundwater flow (based on ${ }^{14} \mathrm{C}$ and tritium groundwater dating) and groundwater recharge estimates (based on the water table fluctuation and chloride mass balance methods) are used to assess the impact of a Eucalyptus globulus plantation on the hydrologic and hydrogeologic regime. This contextualization is then used to discuss the best areas to site tree plantations within low-rainfall catchments.

\section{Background}

This study is part of a multi-site, paired-catchment investigation into the impacts of land use and climate change on the quality and quantity of groundwater and surface water resources in western Victoria, Australia (Adelana et al., 2014; Camporese et al., 2013, 2014; Dean et al., 2014; Dresel et al., 2012).

\subsection{Site description}

The study area consists of a pair of small, adjacent catchments at Mirranatwa in southwestern Victoria - one (referred to as the eucalypt catchment) is covered predominantly in a recently planted (July 2008) E. globulus (Blue Gum) plantation $\left(0.8 \mathrm{~km}^{2}\right)$, the other (referred to as the pasture catchment) is mostly pasture for grazing sheep $\left(0.4 \mathrm{~km}^{2}\right.$; Fig. 1).

\subsubsection{Geology}

Both catchments are underlain by the same weathered/fractured aquifer, the Devonian Dwyer Granite (390$395 \mathrm{Ma}$; Hergt et al., 2007; Van den Berg, 2009). The upper $\sim 20 \mathrm{~m}$ of the granite is well-weathered, porous and 

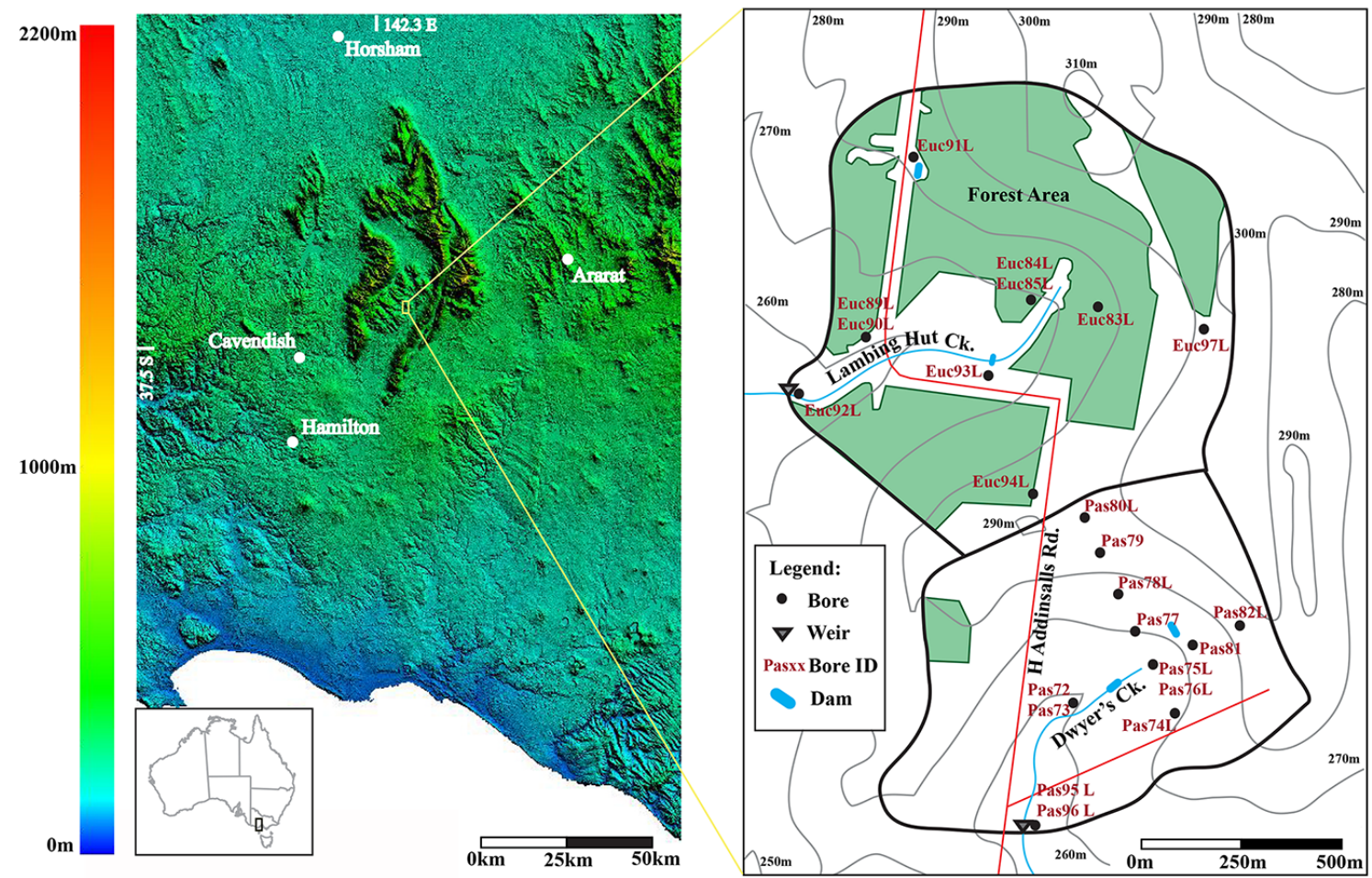

Figure 1. Left: location of the study site in southwestern Victoria, Australia; right: location of the streams, weirs and bores and their reference numbers. "L" denotes the presence of a water level logger in a bore.

permeable saprolite; below this is relatively fresh, fractured bedrock. The fractured granite aquifer extends no deeper than $150 \mathrm{~m}$, as below this depth the fracture conductivity is negligible due to the high lithostatic pressure (Boutt et al., 2010; Cook, 2003; Dept. Sustainability and Environment, 2012). The granite saprolite is generally thicker beneath the lower parts of the catchment than along the ridges, and is overlain by up to $7 \mathrm{~m}$ of alluvial/colluvial material along and adjacent to drainage lines. This alluvium/colluvium is clayrich and impermeable in places, causing temporally variable artesian behaviour in some of the bores along the drainage lines in both catchments. The topography of the site (hills in the middle of a broad valley, Fig. 1) means that both catchments are local groundwater systems, and there are no regional groundwater inputs. There is $50 \mathrm{~m}$ of relief in the eucalypt catchment, and $30 \mathrm{~m}$ in the pasture catchment; both catchments comprise reasonably steep hills separated by a marked break in slope from the more or less flat topography along the drainage lines (Fig. 1).

\subsubsection{Climate and land use}

The climate is Mediterranean, maritime/temperate $(\mathrm{Cfb}$ in the Köppen classification); the average annual rainfall since records began in 1901 for the area is $672 \mathrm{~mm}( \pm 125 \sigma)$, while pan evaporation is around $1350 \mathrm{~mm}$ annually, exceeding rainfall for the majority of the year, excepting the win- ter months of May to September (Dean et al., 2014). Runoff ratios for the pasture and eucalypt catchments are 3.0 and $3.3 \%$ respectively (based on the stream hydrograph records from February 2011 to February 2014), and both streams are ephemeral.

Vegetation of the area prior to European settlement was mostly open eucalypt woodland (Department of Sustainability and Environment, Victoria). Following European settlement there was extensive land clearance, and the catchments were entirely converted to pasture by 1869 (White et al., 2003). $76 \%$ of the northern catchment was subsequently converted to an E. globulus plantation in July 2008 (Fig. 1). Prior to the planting of the eucalypts, the eucalypt plantation catchment (Euc - Table 1) was used for grazing, and was virtually identical to the pasture grazing catchment (Pas - Table 1) immediately to the south. During the planting of the trees the eucalypt catchment was ripped to an average depth of $800 \mathrm{~mm}$ and mounded to an average height of $300 \mathrm{~mm}$. The tree density is 1010 stems per ha ( $2.2 \mathrm{~m}$ between trees along a row, and $4.5 \mathrm{~m}$ between rows), and fertilizer was applied following ripping and mounding at $60 \mathrm{~kg} \mathrm{ha}^{-1}$ (McEwens Contracting, personal communication, 2011). The tree rows run east-west across the slope in the main northeastern part of the catchment, and north-south ( $\sim$ down the slope) to the west of H Addinsalls Road (Fig. 2). 


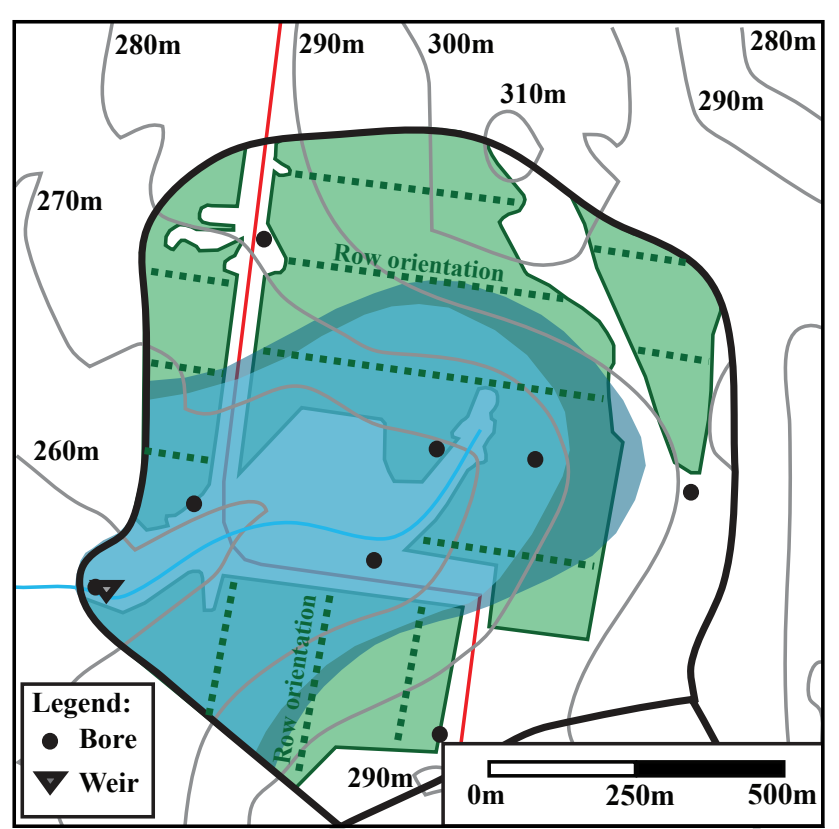

$<6$ m to water table, $30 \%$ of catchment $<8 \mathrm{~m}$ to water table, $38 \%$ of catchment

Figure 2. Orientation of the tree rows in the eucalypt plantation and the area where tree roots may be able to reach groundwater up to depths of 6 and $8 \mathrm{~m}$ below the surface.

\subsubsection{Catchment instrumentation}

The pasture catchment has 13 bores drilled to different depths, and the eucalypt catchment has 10 bores (the bores may be considered to be piezometers - they are screened towards the bottom of the casing over a discrete $2 \mathrm{~m}$ interval; Table 1). Seven bores in the eucalypt catchment and two bores in the pasture catchment were drilled for this project in late 2009; the other bores were installed in the late 1980s in the pasture catchment, and the mid-1990s in the eucalypt catchment. A groundwater logger was installed in every bore in the eucalypt catchment in August 2009, measuring at a minimum $4 \mathrm{~h}$ time interval, and eight bores in the pasture catchment have loggers measuring at the same frequency. There is a v-notch weir at the end of each catchment on both streams, with one bore immediately adjacent to the eucalypt catchment weir and two next to the pasture catchment weir (Fig. 1). The bores adjacent to the weirs have Campbell CS450-L pressure transducers (accuracy $\pm 0.01 \mathrm{~m}$ ) measuring water level and electrical conductivity (EC) at $30 \mathrm{~min}$ intervals, while the other bores have Schlumberger Mini Diver loggers (accuracy $\pm 0.025 \mathrm{~m}$ ) measuring only water level. At the weirs the surface water level was measured using a standard V-notch construction, and electrical conductivity (EC) was recorded using a logger in the weir pool (Dresel et al., 2012). Prior to installation of groundwater log- gers in the older bores, groundwater levels were generally measured manually bi-monthly.

There are two small dams in each catchment, ranging in size from 10 to $50 \mathrm{~m}^{2}$; they are not large enough to significantly impact the hydrology of the site (Fig. 1). The roads at the site are single lane and unsealed, and although they are less permeable than the normal ground surface and therefore promote runoff, their very small area means that they have negligible impact on the site hydrology.

\section{Methods}

Groundwater levels, surface water flow and rainfall data were collected from August 2009 to February 2013 for this study, with some older long-term groundwater level data from manual measurements going back as far as 1986 available from the Victorian Department of Environment and Primary Industries archives. Groundwater and surface chemistry is available from sampling campaigns from August 2010 to $\mathrm{Au}-$ gust 2011 (Dean et al., 2014).

\subsection{Rainfall and streamflow}

Daily rainfall measurements were available from a Bureau of Meteorology station (089019) approximately $2 \mathrm{~km}$ south of the study site; rainfall was also measured in the study catchments and showed an excellent correlation with the Bureau of Meteorology station. Due to significant gaps in the on-site data, the Bureau of Meteorology station data was used for consistency throughout the study period. To determine rainfall patterns, cumulative deviation from the monthly mean (CDM) values were calculated alongside daily values (Sect. 4.1.1), whereby the difference between a given monthly rainfall total and the average for that month (calculated from the entire station's data record of 1901 to 2012), was cumulatively summed from one month to the next (modified from Craddock, 1979). The CDM values represent the longer-term rainfall patterns, with a sustained negative trend for drought periods and positive values indicating wetter than usual periods, and match well with the longer-term hydrographs (Sect. 4.1).

Streamflow in both catchments is ephemeral, and was measured at $30 \mathrm{~min}$ intervals at V-notch weirs at both catchment outlets and summed to annual totals, and a total for the complete study period, 2009-2013. To allow comparison between catchments, volumes were converted to depth equivalents $(\mathrm{mm})$ by dividing by the respective catchment area. Streamflow is derived predominantly from direct runoff, as the proportion of groundwater input into the stream is small (discussed further below).

\subsection{Grain size analysis}

The grain size of the saprolite was used to estimate the average specific yield value for this aquifer over the whole study 
Table 1. Groundwater characteristics and bore construction.

\begin{tabular}{|c|c|c|c|c|c|c|c|c|c|}
\hline Bore ID & $\begin{array}{l}\text { Earliest data } \\
\text { from bore }\end{array}$ & $\begin{array}{c}\text { Screen depth } \\
\text { (m below surface) }\end{array}$ & $\begin{array}{r}\text { Surface elevation } \\
(\mathrm{m} \text { AHD })\end{array}$ & $\begin{array}{l}\text { Radiocarbon age } \\
\text { (BP yr) }\end{array}$ & $1 \sigma-$ error & $\begin{array}{r}\text { Activity of } \\
{ }^{3} \mathrm{H}(\mathrm{TU})\end{array}$ & $1 \sigma-$ error & Logger & $\begin{array}{r}\text { Groundwater } \\
\mathrm{Cl}^{-}\left(\mathrm{mg} \mathrm{L}^{-1}\right)\end{array}$ \\
\hline \multicolumn{10}{|c|}{ Pasture Catchment } \\
\hline Pas72 - Low & 31 Aug 1986 & $9.4-11.6$ & 259.55 & 1665 & \pm 30 & $\mathrm{BD}$ & & $\mathrm{N}$ & 3292 \\
\hline Pas73 - Low & 31 Aug 1986 & 4-6.1 & 259.54 & 2055 & \pm 30 & & & $\mathrm{~N}$ & 3110 \\
\hline Pas75 - Low & 31 Aug 1986 & $12-13.6$ & 263.93 & 935 & \pm 35 & & & $\mathrm{Y}$ & 2231 \\
\hline Pas76 - Low & 31 Aug 1986 & $2.2-4.2$ & 263.98 & 575 & \pm 30 & $\mathrm{BD}$ & & $\mathrm{Y}$ & 1595 \\
\hline Pas95 - Low & 26 Aug 2009 & $22.8-24.8$ & 254.13 & 3540 & \pm 30 & $\mathrm{BD}$ & & Y (weir) & 2732 \\
\hline Pas96 - Low & 26 Aug 2009 & $5-7.55$ & 254.18 & 345 & \pm 25 & 1.12 & \pm 0.09 & Y (weir) & 2553 \\
\hline Pas74 - Up & 31 Aug 1986 & $6.2-8.5$ & 268.62 & 790 & \pm 30 & 0.44 & \pm 0.04 & $\mathrm{Y}$ & 306 \\
\hline Pas77 - Up & 31 Aug 1986 & $17.7-19.7^{\mathrm{a}}$ & 271.11 & Modern & & 2.84 & \pm 0.13 & $\mathrm{~N}$ & 28 \\
\hline Pas78 - Up & 31 Aug 1986 & 17.3-19.4 & 277.45 & 650 & \pm 90 & $\mathrm{BD}$ & & $\mathrm{Y}$ & 1185 \\
\hline Pas79 - Up & 31 Aug 1986 & $23.65-25.65^{\mathrm{a}}$ & 283.23 & Modern & & 2.55 & \pm 0.12 & $\mathrm{~N}$ & 38 \\
\hline Pas 80 - Up & 31 Aug 1986 & $23.3-24.4$ & 288.23 & 115 & \pm 30 & 1.24 & \pm 0.08 & $\mathrm{Y}$ & 2290 \\
\hline Pas81 - Up & 31 Aug 1986 & $7.1-8.9$ & 272.12 & 690 & \pm 100 & 0.79 & \pm 0.08 & $\mathrm{~N}$ & 668 \\
\hline Pas82 - Up & 31 Aug 1986 & $23.2-24.8$ & 283.54 & 430 & \pm 30 & 0.60 & \pm 0.05 & $\mathrm{Y}$ & 329 \\
\hline \multicolumn{10}{|c|}{ Eucalypt catchment } \\
\hline Euc84 - Low & 12 Nov 1996 & $5.6-7.5$ & 268.67 & 785 & \pm 30 & & & $\mathrm{Y}$ & 3909 \\
\hline Euc85 - Low & 12 Nov 1996 & $7.9-10$ & 268.66 & b & & $\mathrm{BD}$ & & $\mathrm{Y}$ & 3537 \\
\hline Euc89 - Low & 30 Oct 2009 & $26-28$ & 261.80 & 7330 & \pm 50 & & & $\mathrm{Y}$ & 2833 \\
\hline Euc90 - Low & 30 Oct 2009 & $13-15$ & 261.93 & 6980 & \pm 45 & & & Y & 2788 \\
\hline Euc92 - Low & 30 Oct 2009 & $26.2-29.2$ & 255.43 & 20770 & \pm 90 & $\mathrm{BD}$ & & Y (weir) & 1490 \\
\hline Euc93 - Low & 2 Mar 2010 & $11-14$ & 263.31 & 725 & \pm 30 & 0.73 & \pm 0.06 & $\mathrm{Y}$ & 1357 \\
\hline Euc83 - Up & 12 Nov 1996 & $14.8-16.7$ & 274.21 & 685 & \pm 30 & $\mathrm{BD}$ & & $\mathrm{Y}$ & 2064 \\
\hline Euc91 - Up & 30 Oct 2009 & $33.9-35.9$ & 280.02 & 415 & \pm 30 & 0.39 & \pm 0.04 & $\mathrm{Y}$ & 1114 \\
\hline Euc94 - Up & 30 Oct 2009 & 28-30 & 286.05 & 2060 & \pm 30 & $\mathrm{BD}$ & & $\mathrm{Y}$ & 2891 \\
\hline Euc97 - Up & 30 Oct 2009 & $\begin{array}{l}43.1-45.1 \\
57.6-59.6\end{array}$ & 291.74 & 5655 & \pm 35 & 0.30 & \pm 0.04 & $\mathrm{Y}$ & 3494 \\
\hline
\end{tabular}

BD: below detectable; ${ }^{\mathrm{a}}$ assumed screen depths; ${ }^{\mathrm{b}} \mathrm{CO}_{2}$ concentration too low for analysis.

site, as the geology of the two catchments is very similar (see Sect. 3.6.1). During drilling of five bores on the eucalypt catchment, samples of the regolith were taken at $1 \mathrm{~m}$ intervals to a depth of $10 \mathrm{~m}$, or until bedrock was encountered. Samples were sieved using a $2 \mathrm{~mm}$ sieve and the material that passed through was then analysed using a Malvern Mastersizer 2000.

\subsection{Groundwater composition}

All 23 groundwater bores across the entire site were sampled once each over a period of a year, from August 2010 to August 2011. Seasonal variability in groundwater composition is considered negligible due to the age of the groundwater at the study site (mostly > 200 years; Table 1), and repeat sampling produced virtually identical field parameters (Dean et al., 2014). Subsamples for $\mathrm{Cl}^{-}$were filtered with $0.45 \mu \mathrm{m}$ filter paper and analysed using Ion Chromatography. Groundwater sampling, $\mathrm{Cl}^{-}$analyses and calculations of volumeweighted, average rainfall $\mathrm{Cl}^{-}$concentrations are described in more detail in Dean et al. (2014).

\section{4 ${ }^{14} \mathrm{C}$ analysis and tritium analysis}

Dating of the groundwater was carried out to determine the time period over which recharge has occurred. Groundwater samples from all the bores at the study site were ${ }^{14} \mathrm{C}$ dated and no corrections were applied, as there is no indication that the radiocarbon ages have been compromised by "dead" carbon in the regolith; standard error of groundwater ages is 25100 years (Dean et al., 2014). In addition, seven bores in the eucalypt catchment and 11 bores in the pasture catchment (including the shallowest and deepest bores and a range in between), were analysed for tritium (standard error in these measurements was 0.04-0.13 tritium units (TU); Dean et al., 2014; Table 1). The methodologies for both are described in more detail in Dean et al. (2014).

\subsection{Radon $\left({ }^{222} \mathrm{Rn}\right)$}

Radon surveys were carried out on groundwater and surface water samples in both catchments to ascertain whether there is a significant contribution of groundwater to surface water flow. The ${ }^{222} \mathrm{Rn}$ content of surface water and groundwater was measured using the gas-extraction for $\mathrm{H}_{2} \mathrm{O}$ accessory of the Durridge RAD-7 radon detector. The RAD-7 is an alpha particle detector that measures the decay of the radon daughters, ${ }^{214} \mathrm{Po}$ and ${ }^{218} \mathrm{Po}$. Samples from weirs, bores and dams (disconnected surface water bodies; Fig. 1) were collected in $250 \mathrm{~mL}$ vials and aerated for $5 \mathrm{~min}$ to degas the radon into the air circulation within the instrument, which takes four measurements ( 5 min each), and then gives the mean ${ }^{222} \mathrm{Rn}$ concentration in $\mathrm{Bq} \mathrm{L}^{-1}$; the average standard error for measurements using this instrument is $10 \%$. 


\subsection{Groundwater recharge}

To ensure robust estimates of groundwater recharge, two different, well-established methods were used, namely the water table fluctuation method and chloride mass balance method. While both methods are in widespread use, they have known deficiencies that are discussed below.

\subsubsection{Water table fluctuations}

The water table fluctuation (WTF) method for measuring groundwater recharge was first applied in the 1920s (Healy and Cook, 2002; Meinzer, 1923) and has since been refined (e.g. Jie et al., 2011; Scanlon et al., 2005; Sophocleus, 1991). The principle of this method is that rises in the groundwater hydrograph of an unconfined aquifer provide an estimate of recharge to the water table, calculated from

$R=S_{\mathrm{y}} \frac{\Delta h}{\Delta t}$,

where recharge $(R)$ is the product of the specific yield of the aquifer $\left(S_{\mathrm{y}}\right)$ and the change in hydrograph height $(\Delta h)$ over a given time interval $(\Delta t)$. This method assumes that recharge occurs vertically from piston flow and that water discharges continuously from the aquifer, causing a drop in the water table when recharge is not occurring. Therefore the change in hydrograph height from which recharge is calculated is the sum of the rise in the hydrograph, together with the decline in the hydrograph that would have occurred in the absence of recharge over the same time period (Healy and Cook, 2002; Jie et al., 2011). Several techniques have been developed to estimate the hydrograph decline: the graphical approach - in which the exponential decay curve of the hydrograph is manually extended to coincide with the peak of the next recharge event (Delin et al., 2007); the master recession curve approach - in which regression functions are assigned to simulate the potential hydrograph decline for each data time-step (Heppner et al., 2007); and the RISE approach - in which the assumption is made that in the absence of recharge, no decline in the water table occurs (Jie et al., 2011; Rutledge, 1998).

It proved difficult to apply the graphical and master recession curve methods in the present study because these methods focus on the section of the hydrograph recession limb which decays exponentially, whereas the recession limbs in the Mirranatwa hydrographs often had significant sections which were steep and straight (Fig. 3); this can lead to the underestimation of actual groundwater recharge, as has been highlighted elsewhere (Cuthbert, 2014). In addition, because the streams in both study catchments are ephemeral, groundwater discharge as baseflow occurs only occasionally; the majority of groundwater discharge occurs at the bottom of the catchments and downstream of the catchment boundaries. This intermittent baseflow means that the recession curve in the hydrographs following a recharge event may not be

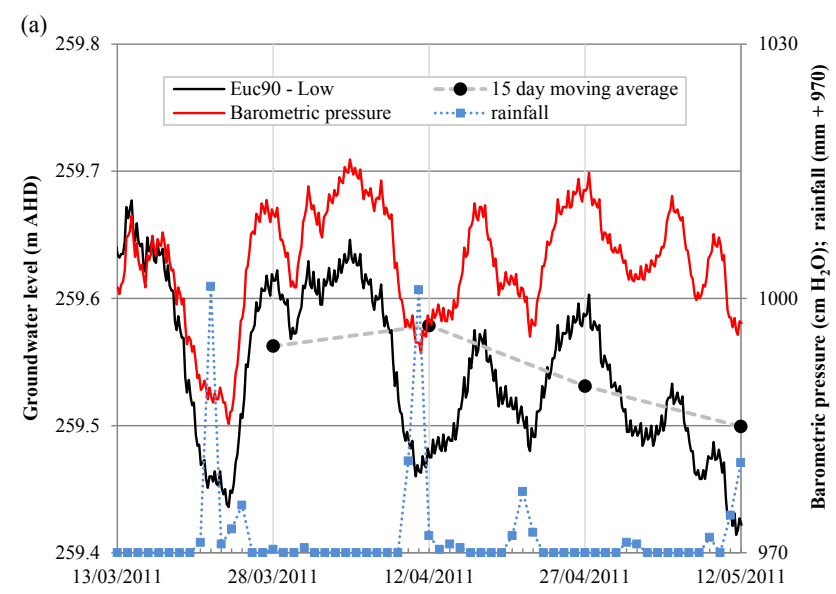

(b)

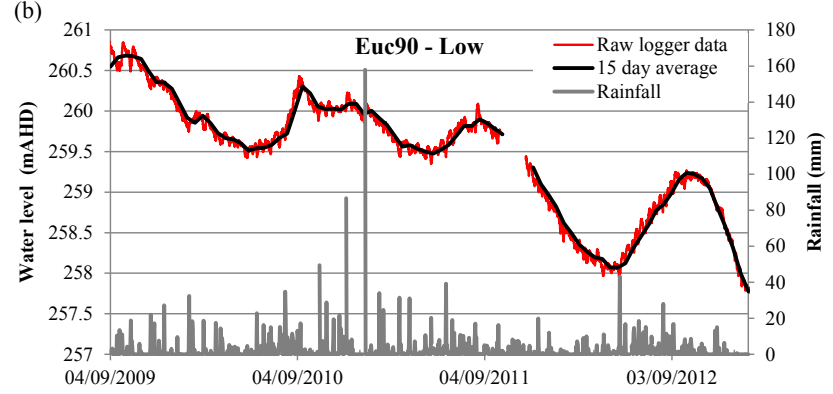

Figure 3. (a) Barometric pressure (in equivalent $\mathrm{cm}$ of $\mathrm{H}_{2} \mathrm{O}$ ), groundwater logger data, rainfall and the 15 day moving average used for the water table fluctuation method estimates of groundwater recharge. The black dots represent the average groundwater level for the preceding 15 days. (b) Full record for the bore used in (a) - Euc90 - showing the complete removal of the large amount of barometric noise, but keeping the overall trend of the 15 day period.

exponential (as observed in the hydrographs). Because the assumption of an exponential recession curve is implicit in the graphical and master recession curve WTF methods, the RISE approach was adopted, i.e. the decay curve of the hydrograph was ignored. Applying the RISE approach means that the values calculated in this study potentially underestimate actual recharge, but when compared with the graphical approach carried out for sections of the hydrographs where exponential recession curves were evident, gave very similar values.

Raw bore hydrograph data collected using data loggers at the site contain small fluctuations due to the impact of barometric pressure on the water column in the bore (Fig. 3a; Rasmussen and Crawford, 1997). The fluctuations in the water level and the barometric pressure are normally inversely correlated (Butler et al., 2011), and can be readily corrected (Rasmussen and Crawford, 1997; Toll and Rasmussen, 2007). At the study site these fluctuations are clearly positively correlated with barometric fluctuations (Fig. 3a), and as a result normal barometric compensation techniques could not be applied. Two types of groundwater level sensors were used: Schlumberger Mini Diver loggers (accuracy 
$\pm 0.025 \mathrm{~m}$ ) and Campbell CS450-L pressure transducers (accuracy $\pm 0.01 \mathrm{~m}$ ); the Campbell sensors are vented and therefore technically do not need compensating for barometric pressure changes, while the Schlumberger sensors require barometric compensation and barometric loggers were installed in the middle of both catchments to collect barometric data for this purpose. The barometric effect shown in Fig. 3a is consistent across all the Schlumberger sensors in both catchments, regardless of landscape position. Figure 3a is based on Fig. 1 from Butler et al. (2011), and the data from this study was prepared in the same manner, so the positive correlation is not an artefact of data processing error. Barometric forcing was evident in the Campbell sensor data also, despite their being vented, so these data were treated in the same way as the Schlumberger data (see below).

A 15-day moving average was used to remove the barometric fluctuations but retain the overall response to rainfall (Fig. 3b). The 15-day time step is a narrow enough time period to incorporate recharge events and reflect the general trend of the hydrograph, but removes the small barometrically forced fluctuations that bear no relationship to rainfall (Fig. 3). Recharge was then calculated using Eq. (1), where $\Delta h$ was taken as the sum of the increases in groundwater level over the time step, and then summed for the entire length of the record. When there was a drop in groundwater level from one time step to the next, this was taken as zero recharge. The measurement uncertainty of the loggers $( \pm 0.025 \mathrm{~m})$ was used as the threshold for recognition of recharge for each 15-day time step. The RISE method was also used to calculate recharge for the longer-term hydrographs (generally bi-monthly measurements taken prior to logger installation).

A specific yield value of $0.095 \pm 0.014$ was calculated for the unconfined saprolite aquifer from the average grain size (clay to coarse sand; Table 2) of all the bore samples analysed (see Sect. 3.2), using the general relationship between specific yield and grain size in Healy and Cook (2002, Tables 1 and 2). The estimation of specific yield is a potential source of considerable error in recharge calculations as it can vary spatially, although it can be assumed to be independent of time (Healy and Cook, 2002). The specific yield value calculated here is comparable to other values from weathered granites in the region $(0.043-$ Hekmeijer and Hocking, 2001; 0.075 - Edwards, 2006). When calculating recharge for the study site, this specific yield was applied to bores that are screened within the saprolite, and is assumed to be representative for the whole site because of the relatively uniform nature of the soils (Table 2).

\subsubsection{Chloride mass balance}

The chloride $\left(\mathrm{Cl}^{-}\right)$mass balance (CMB) method for calculating recharge is based on the relationship between $\mathrm{Cl}^{-}$in groundwater and in precipitation, assuming that all $\mathrm{Cl}^{-}$in the groundwater is derived from rainfall and remains in solu-
Table 2. Median grain size compositions for sampled profiles used to estimate a range of values for $S_{\mathrm{y}}$ in Eq. (1).

\begin{tabular}{lrrrr}
\hline Bore ID & $\begin{array}{r}\text { Clay } \\
(\%)\end{array}$ & $\begin{array}{r}\text { Silt } \\
(\%)\end{array}$ & $\begin{array}{r}\text { Fine sand } \\
(\%)\end{array}$ & $\begin{array}{r}\text { Coarse sand } \\
(\%)\end{array}$ \\
\hline Euc89 - Low & 3 & 39 & 38 & 19 \\
Euc91 - Low & 3 & 39 & 40 & 18 \\
Euc93 - Low & 3 & 36 & 43 & 18 \\
Euc94 - Up & 3 & 35 & 44 & 18 \\
Euc97 - Up & 3 & 34 & 43 & 20 \\
\hline
\end{tabular}

tion within the groundwater system, that direct recharge $(R$, in $\mathrm{mm}$ ) occurs via piston flow, and that runoff is negligible:

$R=P \frac{C_{p}}{C_{\mathrm{gw}}}$,

where $P$ is the amount of rainfall $(\mathrm{mm}), C_{p}$ is the concentration of $\mathrm{Cl}^{-}$in $P$, and $C_{\mathrm{gw}}$ is the concentration of $\mathrm{Cl}^{-}$in groundwater (Allison and Hughes, 1978; Scanlon et al., 2002). $R$ was calculated at all bores using the groundwater $\mathrm{Cl}^{-}$content (Table 1), and rainfall $\mathrm{Cl}^{-}$content was the median value from three different sampling periods at nearby sites (Fig. 1): 1954-1955 at Cavendish (Hutton and Leslie, 1958), 2003-2004 at Hamilton (Bormann, 2004), and 2007-2010 at Horsham (Nation, 2009); all $\mathrm{Cl}^{-}$values were volume weighted based on rainfall during the sampling periods in these studies. These three sampling periods include a wet period (1954-1955) and two dry periods (20032004 and 2007-2009). The median rainfall $\mathrm{Cl}^{-}$from all of these studies is $4.3 \pm 0.9 \mathrm{mg} \mathrm{L}^{-1}$, and the annual rainfall is $672 \pm 125 \mathrm{~mm}(1 \sigma)$; the uncertainties associated with each value were used to estimate the overall uncertainty in the recharge values calculated. $R$ is strongly governed by $C_{p}$ in this equation, so it is important to take into account the variability in $C_{p}$.

\section{Results and discussion}

\subsection{Groundwater recharge estimates}

Recharge estimates calculated using both the WTF and CMB methods range from $0.8 \pm 0.3$ to $161 \pm 24 \mathrm{~mm} \mathrm{yr}^{-1}$ (Table 3), a very wide range that matches recharge calculations from similar climatic areas in Australia $\left(5-250 \mathrm{~mm} \mathrm{yr}^{-1}\right.$; Allison and Hughes, 1978; Cook et al., 1989), and elsewhere from low-rainfall regions around the world $\left(0.2-35 \mathrm{~mm} \mathrm{yr}^{-1}\right.$; Scanlon et al., 2006).

\subsubsection{Water table fluctuation method}

The groundwater hydrographs vary significantly across the study site (Fig. 4), indicating substantial variation in groundwater recharge. Because hydrographs from the upper parts 
Table 3. Recharge $(R)$ values using different methods for all the bores across both catchments.

\begin{tabular}{|c|c|c|c|c|}
\hline \multirow[b]{2}{*}{ Bore ID } & \multicolumn{4}{|c|}{$R\left(\mathrm{~mm} \mathrm{yr}^{-1}\right)$} \\
\hline & $\begin{array}{l}\text { Groundwater } \\
\mathrm{Cl}^{-}\end{array}$ & $\begin{array}{l}\text { Groundwater } \mathrm{Cl}^{-} \text {with } \\
\text { stream input correction }\end{array}$ & $\begin{array}{c}\text { Water table } \\
\text { fluctuation method }\end{array}$ & $\begin{array}{l}\text { Long-term hydrograph water } \\
\text { table fluctuation method }\end{array}$ \\
\hline \multicolumn{5}{|c|}{ Pasture catchment - lowland landscape position } \\
\hline Pas 72 - Low* & $0.9 \pm 0.3$ & $6.8 \pm 4.6$ & $L$ & $D$ \\
\hline Pas 73 - Low* & $0.9 \pm 0.3$ & $7.2 \pm 4.8$ & $L$ & $D$ \\
\hline Pas 75 - Low & $1.3 \pm 0.5$ & $3.9 \pm 2.6$ & $58 \pm 9$ & $38 \pm 6$ \\
\hline Pas 76 - Low & $1.8 \pm 0.7$ & $5.5 \pm 3.7$ & $77 \pm 11$ & $D$ \\
\hline Pas95 - Low* & $1.1 \pm 0.4$ & $24 \pm 16$ & C & $D$ \\
\hline Pas96 - Low & $1.1 \pm 0.4$ & $26 \pm 17$ & $161 \pm 24$ & $D$ \\
\hline \multicolumn{5}{|c|}{ Pasture catchment - upland landscape position } \\
\hline Pas78 - Up & $2.5 \pm 0.9$ & $C$ & $36 \pm 5$ & $D$ \\
\hline Pas 80 - Up & $1.0 \pm 0.4$ & $C$ & $12 \pm 2$ & $30 \pm 5$ \\
\hline Pas82-Up & $8.8 \pm 3.3$ & $C$ & $26 \pm 4$ & $28 \pm 4$ \\
\hline \multicolumn{5}{|c|}{ Pasture catchment - possible fracture flow } \\
\hline Pas74 - Up & $9.4 \pm 3.5$ & $C$ & $65 \pm 10$ & $56 \pm 8$ \\
\hline Pas77 - Up & $102 \pm 38$ & $C$ & $L$ & $D$ \\
\hline Pas79 - Up & $76 \pm 29$ & $C$ & $L$ & $D$ \\
\hline Pas81 - Up & $4.3 \pm 1.6$ & $C$ & $L$ & $D$ \\
\hline \multicolumn{5}{|c|}{ Eucalypt catchment - lowland landscape position } \\
\hline Euc84 - Low* & $0.7 \pm 0.3$ & $1.7 \pm 1.3$ & $C$ & $C$ \\
\hline Euc85 - Low* & $0.8 \pm 0.3$ & $1.9 \pm 1.4$ & $C$ & $C$ \\
\hline Euc89 - Low & $1.0 \pm 0.4$ & $5.7 \pm 4.3$ & $59 \pm 9$ & $D$ \\
\hline Euc90 - Low & $1.0 \pm 0.4$ & $5.8 \pm 4.4$ & $74 \pm 11$ & $D$ \\
\hline Euc93 - Low & $2.1 \pm 0.8$ & $8.0 \pm 6.1$ & $40 \pm 6$ & $D$ \\
\hline \multicolumn{5}{|c|}{ Eucalypt catchment - upland landscape position } \\
\hline Euc83 - Up & $1.4 \pm 0.5$ & $C$ & $10 \pm 2$ & $19 \pm 3$ \\
\hline Euc91 - Up & $2.6 \pm 1.0$ & $C$ & $17 \pm 3$ & $D$ \\
\hline Euc94 - Up & $1.0 \pm 0.4$ & $C$ & $1.7 \pm 0.2$ & $D$ \\
\hline Euc97 - Up & $0.8 \pm 0.3$ & $C$ & $26 \pm 4$ & $D$ \\
\hline \multicolumn{5}{|c|}{ Eucalypt catchment - possible fracture flow } \\
\hline Euc92 - Low* & $1.9 \pm 0.7$ & $C$ & $C$ & $D$ \\
\hline
\end{tabular}

of the catchment show a limited response to rainfall patterns, both in the detailed groundwater logger data (Fig. 4) and the longer-term monitoring data for the older bores (Fig. 5), recharge values calculated using the WTF method are relatively low for these areas in both catchments (average $18 \mathrm{~mm} \mathrm{yr}^{-1} ; 3 \%$ of rainfall).

In contrast, bores on or close to drainage lines show a much greater sensitivity to sustained rainfall and streamflow events (e.g. for bore Pas96, rises in the hydrograph directly correspond to flow in the ephemeral stream channel; Fig. 6). As a result, recharge values calculated from logger data and longer-term hydrographs using the WTF method are relatively high for low-lying areas in both catch- ments (average $78 \mathrm{~mm} \mathrm{yr}^{-1} ; 12 \%$ of rainfall; Fig. 4; Table 3 ). These recharge trends have been consistent over the past 20 30 years (Fig. 5).

The greater recharge in the lower-lying areas is predominantly because the steeper slopes in the upland areas direct runoff downslope to the lowland areas, which are consequently saturated for longer with a greater volume of runoff. In addition, runoff velocities across the lower areas decrease due to the reduction in slope, allowing more infiltration into the soil. Runoff from the upland areas is aided by the low-permeability, silty soils (Table 2), and infiltration in the lower-lying areas, particularly through the streambed, is increased by the greater depth of weathering $(9 \mathrm{~m}$ depth to 

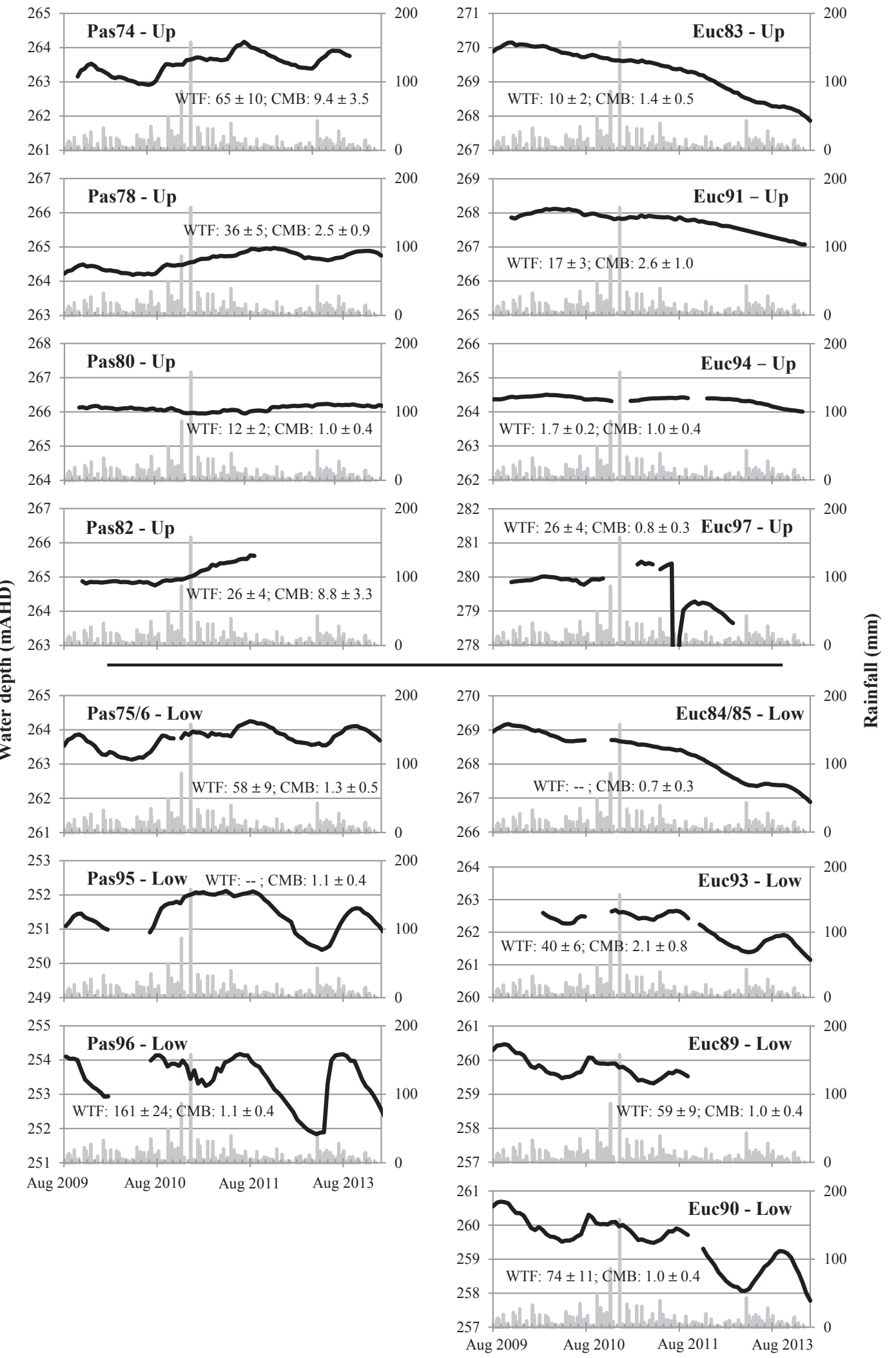

Figure 4. Bore hydrographs, rainfall and recharge estimates (in $\mathrm{mm} \mathrm{yr}^{-1}$ from Table 3), for the water table fluctuation and chloride mass balance methods. Hydrographs are sorted by landscape position - lowland or upland. 


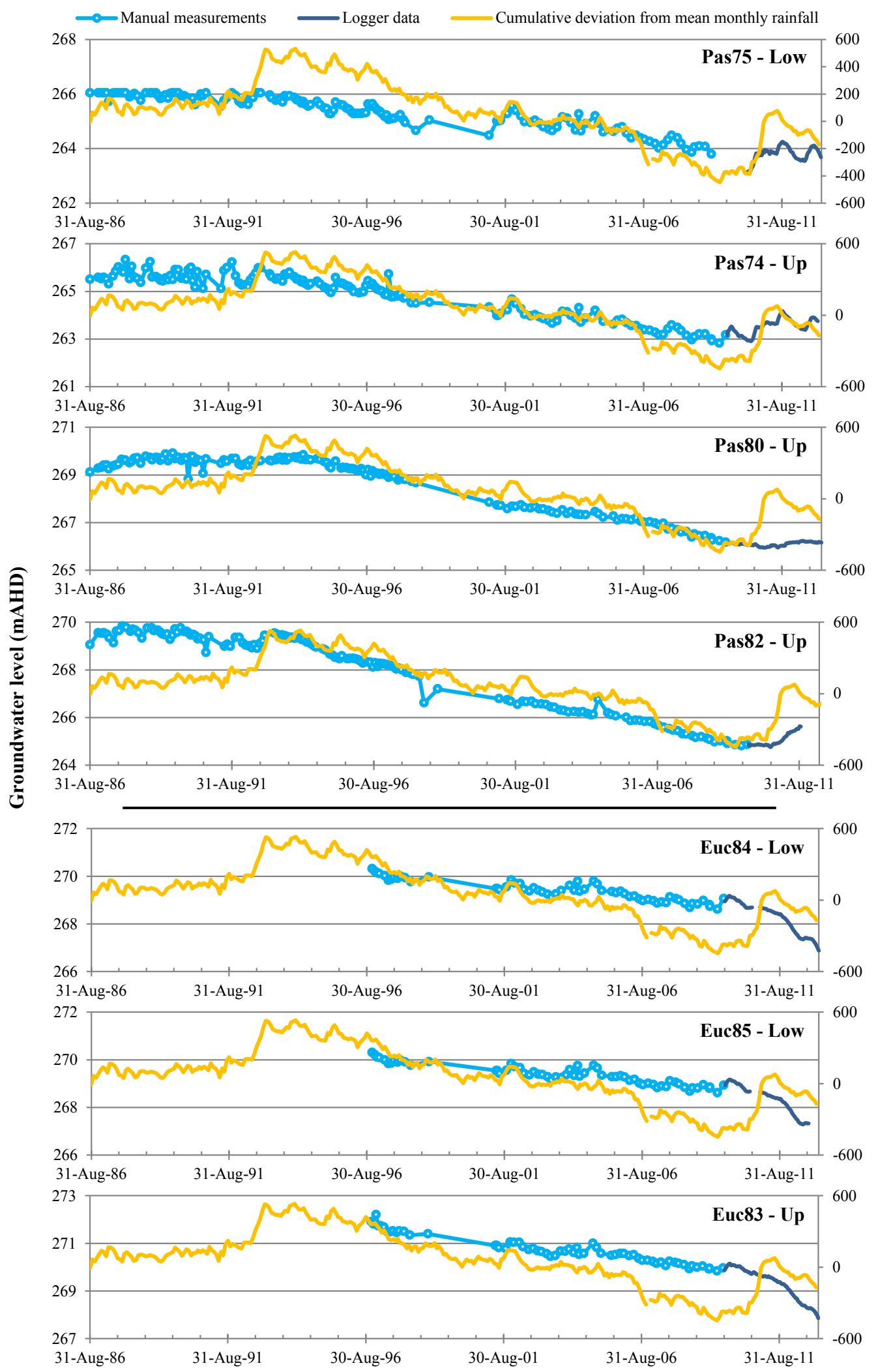

Figure 5. Long-term hydrographs for bores with available data and cumulative deviation from mean monthly rainfall to show the relationship between groundwater levels and long-term rainfall patterns. 


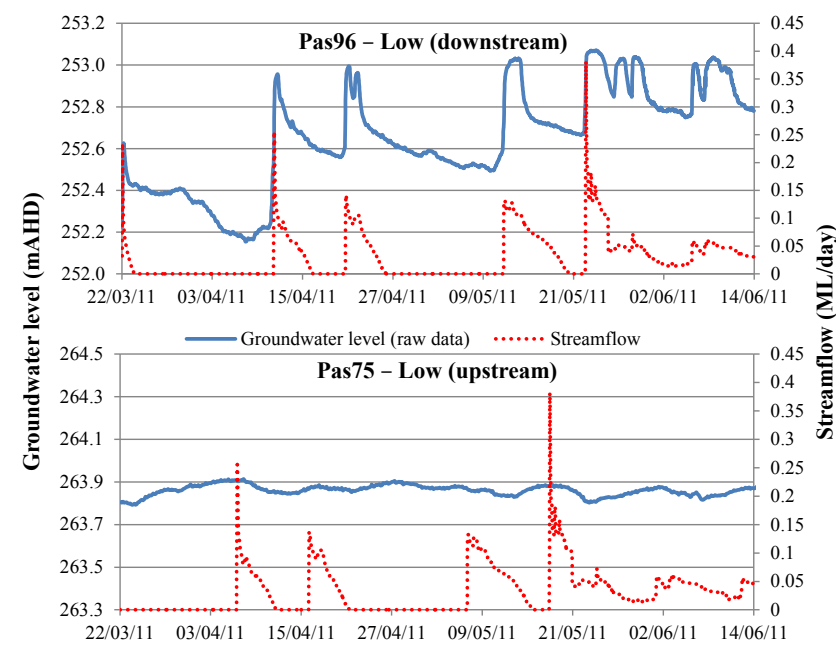

Figure 6. Pasture stream hydrographs (Dwyer's Creek) and bores hydrographs from the bottom of the catchment (Pas96) and midway up the catchment (Pas75).

bedrock in the pasture catchment and $30 \mathrm{~m}$ in the eucalypt catchment, except at the very bottom of this catchment).

Two of the lowland bores (Euc84 and Euc85) show very similar recharge patterns to upland bores (e.g. Euc83), i.e. little recharge, due to the presence of a localized confining layer (both bores frequently go artesian; Fig. 4).

Two of the upper-slope bores show high recharge (Pas74 and Pas 78), due to preferential recharge down fractures in the granite (Sect. 4.2; Fig. 5).

\subsubsection{Chloride mass balance method}

Recharge values calculated from the CMB method (Eq. 2) are much lower than the WTF method values, often by an order of magnitude or more (Table 3): e.g. Pas96 has recharge values of $1.1 \pm 0.4 \mathrm{~mm} \mathrm{yr}^{-1}(\mathrm{CMB})$ and $161 \pm 24 \mathrm{~mm} \mathrm{yr}^{-1}$ (WTF), and Pas 82 has a CMB value of $8.8 \pm 3.3 \mathrm{~mm} \mathrm{yr}^{-1}$ and a WTF value of $26 \pm 4 \mathrm{~mm} \mathrm{yr}^{-1}$. Furthermore, the bore hydrographs used to calculate the WTF recharge values indicate that there is much more recharge occurring in the lowland areas than is indicated by the CMB values.

The most likely explanation for the mismatch between the CMB and WTF results is that the input $\mathrm{Cl}^{-}$value used in the CMB method should be for runoff/streamflow rather than rainfall, because most recharge occurs from infiltration of surface flow through the streambed and across the lowgradient slopes adjacent to the streams, as previously discussed.

To account for this difference, the CMB values were recalculated using the volume and $\mathrm{Cl}^{-}$content of streamflow (assumed to be the same as runoff here) in place of rainfall in Eq. (2):

$$
R=\mathrm{RO} \frac{C_{\mathrm{ro}}}{C_{\mathrm{gw}}}
$$

where "RO" (mm) is the estimated amount of runoff that would reach a given bore, and $C_{\mathrm{ro}}$ is the estimated $\mathrm{Cl}^{-}$concentration of the runoff (volume weighted).

The volume of runoff at a particular bore (RO) is calculated using streamflow as a proxy for runoff, by dividing the average streamflow per year by the amount of the catchment that could theoretically provide runoff to the bore location (i.e. a bore in the middle of the catchment is only going to receive approximately half the runoff that could potentially recharge a bore at the bottom of the catchment). The $\mathrm{Cl}^{-}$ concentration of the runoff $\left(C_{\mathrm{ro}}\right)$ is calculated from the average EC measured at each weir (May 2010 to February 2013), converted to $\mathrm{Cl}^{-}$using the $\mathrm{EC}: \mathrm{Cl}^{-}$ratio for the study site data set ( 0.39 and 0.37 for the pasture and eucalypt catchments respectively). Equation (3) was only applied to bores in the lowland parts of the landscape where runoff is likely to recharge the groundwater. Because of the highly variable nature of the streamflow $\mathrm{Cl}^{-}$, the potential variation in recharge values calculated from Eq. (3) is large, and this is seen in the error values $(1 \sigma-$ Table 3$)$.

The recalculated recharge values generated from Eq. (3) are much closer to the WTF recharge values, but are still generally a factor of 5 to 15 lower. This may reflect the fact that the groundwater across the study site is mostly $>200$ years old, indicating that the CMB values are generally representative of recharge rates under native vegetation prior to land clearance during European settlement in the late 1800 s, whereas the WTF values represent recent recharge (August 2009 to February 2013). The older, pre-European settlement vegetation caused lower recharge, as these trees transpire much more water from groundwater and the soil zone than modern pasture. This disparity between modern and pre-European recharge rates has been observed elsewhere in southeastern Australia (e.g. Allison et al., 1990; Bennetts et al., 2006, 2007; Cartwright et al., 2007).

The CMB method estimates of recharge do not vary significantly between the two catchments, showing that both catchments behaved in a similar fashion before measurements began, prior to the establishment of the plantation. This corrects for the lack of a calibration period prior to the change in land use, a potential source of considerable error (Brown et al., 2005).

\subsection{Topographic controls on recharge}

Recharge estimates using the WTF method (Table 3) show that within the local groundwater systems of the study catchments, variations in recharge predominantly reflect differences in topography. Dominant areas of recharge are not along the topographic highs of the catchments, as in the traditional conceptual model of recharge, but are instead analogous with more arid regions, where most recharge occurs in topographic depressions (Scanlon et al., 2002).

Recharge rates increase as surface elevation decreases (Fig. 7). The steeper slopes of the upland areas promote 


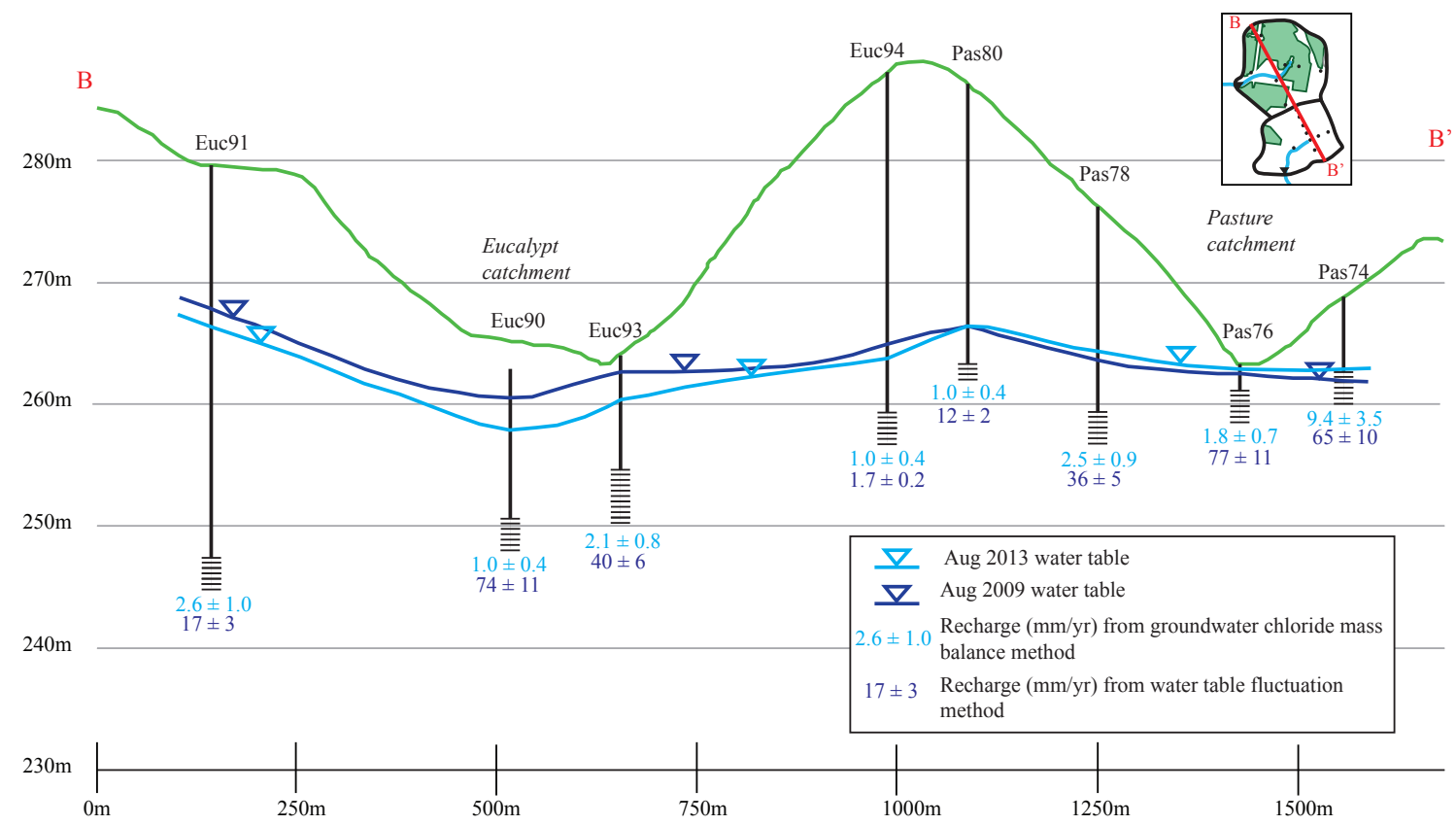

Figure 7. Cross-section from bore Euc91 across both catchments to bore Pas74 showing recharge rates based on both methods used in this study, and the water table change over the course of the study period (see Fig. 1 for bore locations).

runoff rather than infiltration, aided by low-permeability, silty soils (Table 2). Overland flow is focused into topographic lows and along drainage lines. Here the granite is most weathered, as indicated by the greater depth to bedrock here $(9 \mathrm{~m}$ in the pasture catchment, and $30 \mathrm{~m}$ in the eucalypt catchment except at the very bottom of this catchment), encouraging recharge to occur, particularly through the streambed.

\subsection{Influence of fractures on groundwater recharge}

The ${ }^{14} \mathrm{C}$ data (Table 1) show that most of the groundwater at the study site is older than the tree plantation, but the groundwater in some bores (Pas74, Pas 80, Pas81, Pas 82, Pas 96, Euc91, Euc93 and Euc97) also contains measurable tritium, indicating a component of younger groundwater $(<50$ years old). Recharge in fractured rock aquifers like granite is controlled to some extent by the fracture network (Cook, 2003), which forms multiple recharge pathways. In the study area this has allowed mixing of young groundwater (containing tritium) with much older groundwater (as shown by the ${ }^{14} \mathrm{C}$ dates; Table 1). The hydrograph for the upslope bore Pas 74 (Fig. 4) shows high recharge following rainfall events (in contrast to most of the other upslope bores), most likely because it is located on a fracture in the granite that allows rapid recharge, as shown by the dilute groundwater with low $\mathrm{Cl}^{-}$ concentrations (Dean et al., 2014) and the presence of significant amounts of tritium (Table 1).

This dual porosity (matrix and fracture flow) influence on recharge has been observed elsewhere in southeastern Aus- tralia where there was disparity between the residence times of groundwater samples (Cartwright et al., 2007). Nevertheless, the dominant recharge control across both catchments is topography rather than fracture heterogeneity, as shown by the relatively flat hydrographs for most of the upland bores, and strongly oscillating hydrographs in the lowland bores (Fig. 4).

\subsection{The interplay between ephemeral streamflow and groundwater recharge and discharge}

The streams at the study site are ephemeral, flowing on average only $40 \%$ of the time at the catchment outlets. When they are dry, recharge can occur readily along and near the streambeds as upwards groundwater gradients are not present, because the water table is below the base of the stream. As a result, bores in the lower parts of the catchments (e.g. Pas96 near the outlet of the pasture catchment; Fig. 6) show a clear, sometimes instantaneous link between recharge and runoff.

Following extended periods of wet weather, the ephemeral stream at the bottom of the eucalypt catchment is fed by groundwater discharge, as shown by the significant levels of ${ }^{222} \mathrm{Rn}$ measured at the weir $\left(11 \mathrm{~Bq} \mathrm{~L}^{-1} ;\right.$ Fig. 8); however, the elevated ${ }^{222} \mathrm{Rn}$ measured in the eucalypt stream could just be due to the close proximity of the granite bedrock to the surface at the bottom of this catchment. This is suggested by the high ${ }^{222} \mathrm{Rn}$ values in Pas95 and Euc92, both screened in granite bedrock, compared to the lower ${ }^{222} \mathrm{Rn}$ values in Euc90 and Pas96, which are screened in the weathered gran- 


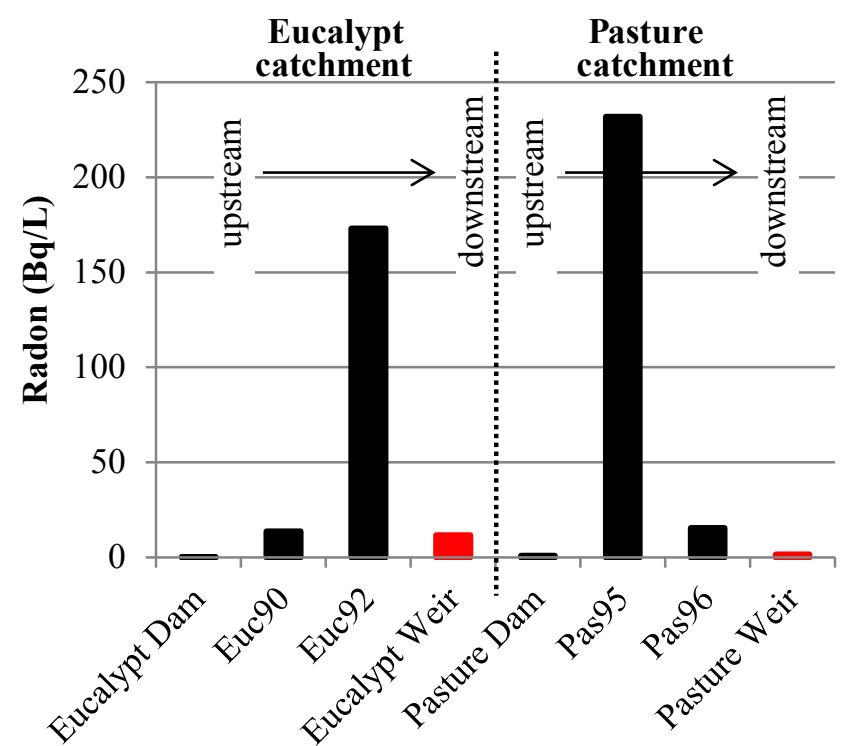

Figure 8. ${ }^{222} \mathrm{Rn}$ concentrations in the streams, measured at the weirs of both sites, and nearby bores. Surface water from further up the catchments is represented by water from dams located upslope in both catchments. The relatively high levels in the groundwater are a result of the decay of uranium present in the allanite and zircon of the granite.

ite saprolite (Fig. 8). Regardless, the shallow granite bedrock at the outlet of the eucalypt catchment (less than $2 \mathrm{~m}$ below the surface; Fig. 9) forces groundwater towards the surface here. In contrast, the bedrock at the bottom of the pasture catchment is $9 \mathrm{~m}$ deep, so the water table lies more consistently below the base of the stream and there is less groundwater discharge; as a result, the pasture catchment has fewer low flows than the eucalypt catchment (Fig. 9) and lower ${ }^{222} \mathrm{Rn}$ levels (1 $\mathrm{Bq} \mathrm{L}^{-1}$ at the weir; Fig. 8).

In both catchments, during periods of little or no rainfall, the water table lies below the surface, so recharge can occur along the length of the channel. When it begins to rain and the system wets up, the water table rises at the downstream end of the catchment and groundwater begins to discharge here (this occurs more frequently and to a greater extent in the eucalypt catchment). Continued rain raises the water table so it connects to the stream further upstream, increasing the length of the stream that receives groundwater discharge (Fig. 9; Adelana et al., 2014). When rainfall ceases, the water table drops and progressively disconnects from the stream, starting upstream, until it is completely disconnected throughout the catchment. This means that during smaller rainfall events, when the water table remains below the land surface and does not connect to the stream, recharge occurs along the length of the stream. During larger rainfall events, as the water table comes to the surface along the stream channel, the area of potential recharge decreases.

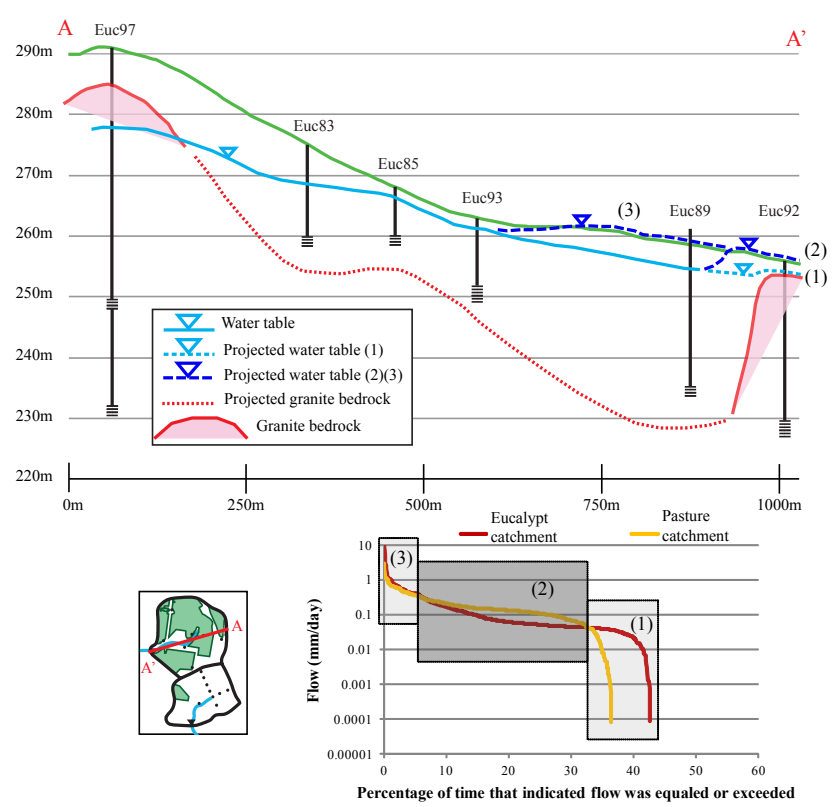

Figure 9. Long section from bores Euc97 to Euc92 showing the effect of the shallow granite on the water table under different flow conditions shown in the flow duration curve below: (1) where low flows in the eucalypt catchment stream are sustained for longer due to some groundwater discharge compared to virtually no groundwater discharge in the pasture catchment, (2) where the water table is at the surface and runoff is transported more quickly out of the eucalypt than in the pasture catchment, and (3) where there are some rare, very high flows, much higher than observed in the pasture catchment.

The groundwater hydrographs indicate that during the study period, recharge occurred readily in the lowland areas of both catchments, particularly when there was enough rainfall to generate consistent flow in the streams, while much less recharge is evident on the upper slopes. There is relatively little groundwater discharge along the streams, as shown by the ${ }^{222} \mathrm{Rn}$ data (Fig. 8), and groundwater within the catchments is lost predominantly through evapotranspiration, particularly when the water table is within $2 \mathrm{~m}$ of the ground surface (as commonly occurs in southeastern Australia, e.g. Bennetts et al., 2006, 2007); a small amount flows out at the bottom of the catchment.

\subsection{Vegetation controls on recharge}

The bore hydrographs in the eucalypt catchment show a clear overall declining trend of up to $3 \mathrm{~m}$ during the study period, evident even in artesian bores (Euc84 and Euc85), and regardless of landscape position (Fig. 4). This decline is not evident in hydrographs from the pasture catchment (Fig. 4), where the water table has increased by $0.5-1 \mathrm{~m}$ during the whole study period as a result of consecutive wet summers of 2010/2011 and 2011/2012 (Fig. 7). The tree plantation was a little over 1 year old when the main measurements of this 
study began, and as the age of the plantation increased, a steeper decline in groundwater depth was observed (Fig. 4).

The water level decrease in the eucalypt catchment, with no corresponding drop in the pasture catchment, is attributed to greater water use by the trees, as has been demonstrated elsewhere (e.g. Adelana et al., 2014; Bosch and Hewlett, 1982). The water table decline is less in the upland areas (Fig. 9), probably because recharge rates here are lower, so that the decrease in recharge due to tree water use has had relatively little impact. Furthermore, in the upland areas the water table is too deep for the vegetation to access the groundwater directly; Benyon et al. (2006), in a study in the same region of southeastern Australia, found that deep-rooted eucalypts can only access groundwater up to a depth of 6-8 m. In the lowland areas the trees are able to reach the groundwater (Fig. 2), and this, combined with the interception of potential recharge in the soil zone by the growing plantation, causes the observed decline in groundwater level (Fig. 4). Although tree roots can provide preferential pathways for infiltration of rainfall to the water table (Burgess et al., 2001), any effect of this is masked by the overall impact of eucalypt water use. The increasing rate of decline in groundwater depth over time can be attributed to the greater water usage by the trees as they grow (Fig. 4).

The narrow areas immediately adjacent to the drainage lines in the eucalypt catchment are covered in grass and therefore there is less direct interception of potential recharge, but in fact these areas show the biggest decline in groundwater level (Fig. 7). The highest rates of recharge occur along the drainage lines and the adjacent trees will therefore have a substantial impact there, in particular because they are directly accessing the groundwater.

With groundwater levels in the eucalypt catchment still in decline at the end of the study period, five years since the establishment of the eucalypt plantation, there is no sign that the system is reaching equilibrium under the new land use. Brown et al. (2005) indicate that equilibrium would not be expected until more than 5 years after the land use change occurred.

\subsection{Management of tree plantations and recharge}

Afforestation of farmland was widespread in southeastern South Australia and southwestern Victoria (known as the Green Triangle) from the 1980s through to the 2000s, with the plantation area expanding by 5-14\% to 30000 ha in Victoria alone (Adelana et al., 2014; Benyon et al., 2006; Ierodiaconou et al., 2005). However, the subsequent development of tree plantations in the region has been hindered by a poor timber market (HVP Plantations, personal communication, 2013) and concerns that plantations use more groundwater and surface water than other land uses like farming. As a result, tree plantations in the state of South Australia must now be licensed as groundwater users (Govt. of South Australia, 2009), while it is hoped that the potential reduction in water availability resulting from reforestation will be offset by the beneficial gains of the carbon sequestration within the new trees (Schrobback et al., 2011).

A reduction of groundwater recharge by plantations, as documented in this study, lowers the water table and can reduce stream flow. If this is the object of the reforestation, for example to reduce saline groundwater discharge, then this land use change may well serve its purpose (Bennetts et al., 2007). However, the recent drought in southeastern Australia (1997-2010) has exacerbated concerns that trees may be a significant user of local and regional water resources, reducing groundwater recharge, discharge and surface water availability (Jackson et al., 2005).

In order to reduce the impact on water availability, current regulation of tree plantations in southeastern Australia focuses on the percentage of a catchment that may be planted. However, the present study shows that the location of the plantation within the catchment is significant also, with a smaller water table decline seen in the upland areas of the eucalypt catchment. Therefore to reduce the impact of plantations on groundwater recharge, tree planting should be avoided in the dominant zone of recharge, i.e. the topographically low areas and along the drainage lines, and should be concentrated on the upper slopes, where the water tables are deeper and the trees are less likely to access the groundwater and transpire it directly. At present, tree plantations in Victoria cannot be planted within $20 \mathrm{~m}$ of drainage lines, to avoid erosion of creek banks when the trees are removed (Dept. of Environment and Primary Industries, Victoria); we suggest that this currently restricted area along the drainage lines be expanded to include as much of the low topography parts of the site as practicable.

The expansion of the drainage line exclusion zone in tree plantations will have an added benefit in many regions of southeastern Australia where the groundwater is saline. This is because the parts of the catchments where the saline groundwater is within a few metres of the land surface (generally the lowland areas) can have a negative effect on tree health; at the study site, the trees closer to the drainage lines are shorter and thinner than those upslope.

However, excluding tree planting from low-elevation areas reduces the number of trees that can be planted within a catchment, and also means that trees are not planted in areas where (good quality) groundwater is shallowest and can be most readily accessed for tree growth. As the primary purpose of many tree plantations is the production of wood and pulp products for economic gain, this restriction will slow economic returns. To overcome this, consideration could be given to planting lower-water-use trees that can better cope with the upslope areas where water supplies for tree growth may be limited.

This management strategy of balancing economic and hydrologic perspectives when locating tree plantations within catchments will be applicable to other low-rainfall, high- 
evaporation regions, and should be considered for tree plantations in similar climatic areas worldwide.

\section{Conclusions}

While the importance of topography and ephemeral streams to focused recharge in low-rainfall regions around the world has been known for some time, the implications of this aspect of the groundwater resource literature have not been incorporated into plantation management guidelines and legislation. In this study, it is shown that the majority of modern recharge at the study site, calculated from the water table fluctuation method, occurs in the lower parts of both study catchments ( $12 \%$ of rainfall versus $3 \%$ in the upland areas). Overland flow is focused into topographic lows and along drainage lines where greater infiltration can occur. Recharge calculations using a corrected chloride mass balance method gave lower values than modern recharge estimates because the groundwater across the study site is mostly $>200$ years old, representing recharge under native eucalypt forest prior to European land clearance. Relatively little groundwater discharges into the streams or flows out at the bottom of the catchment; groundwater within the catchments is lost predominantly through evapotranspiration. Overall the tree plantation in this study caused a drawdown in groundwater levels, increasing over time as the trees aged, compared to a slight rise in groundwater levels in the pasture catchment.

The results of this study lead to the conclusion that both the hydrogeological and economic frameworks for commercial forestry need to be considered. If conserving groundwater recharge is a primary objective, tree planting should be avoided in the dominant zone of recharge, and concentrated on the upper slopes, where recharge is low enough that any further reduction will have minimal impact. We suggest expanding present regulations for tree plantations which specify that trees cannot be planted within a certain distance of drainage lines, including as much of the low topography parts of the site as practicable. Consideration should be given to the potential negative impact on the financial viability of a tree plantation. This management strategy is applicable to low-rainfall, high-evaporation regions worldwide.

Acknowledgements. This work would not have been possible without the assistance and support of the land owners, Iven, Iris and Marcia Field, Macquarie Bank Foundation, and the plantation management, McEwen's Contracting Pty Ltd. We would like to acknowledge Phil Cook and Peter Hekmeijer at the Department of Primary Industries Victoria, our collaborators in the National Centre for Groundwater Research and Training (of which this research is part of programme 4 - http://www.groundwater.com.au) for funding and support, the Australian Institute of Nuclear Science and Engineering (AINSE - grant number AINSTU0710) for funding and support, and funding from the State of Victoria through the Department of Environment and Primary Industries, Future Farming Systems Research Division. We would also like to thank
Ian Cartwright, Guillaume Bertrand, a third anonymous reviewer and the editor, Przemyslaw Wachniew, for their constructive feedback and helpful comments throughout the review process.

Neither the NCGRT, AINSE nor DEPI Victoria (as funding sources) were involved in the design of this specific study, nor were they involved in the collection or analysis of the resulting data.

Edited by: P. Wachniew

\section{References}

Adelana, M., Dresel, E., Hekmeijer, P., Zydor, H., Webb, J., Reynolds, M., and Ryan, M.: A comparison on streamflow and water balances in adjacent farmland and forest catchments in south-western Victoria, Australia, Hydrol. Process., doi:10.1002/hyp.10281, online first, 2014.

Allison, G. B. and Hughes, M. W.: The use of environmental chloride and tritium to estimate total recharge to an unconfined aquifer, Aust. J. Soil Res., 16, 181-195, 1978.

Allison, G. B., Cook, P. G., Barnett, S. R., Walker, G. R., Jolly, I. D., and Hughes, M. W.: Land clearance and river salinisation in the western Murray Basin, Australia, J. Hydrol., 119, 1-20, 1990.

Bell, R. W., Schofield, N. J., Loh, I. C., and Bari, M. A.: Groundwater response to reforestation in the Darling Range of Western Australia, J. Hydrol., 115, 297-317, 1990.

Bennetts, D. A., Webb, J. A., Stone, D. J. M., and Hill, D. M.: Understanding the salinisation process for groundwater in an area of south-eastern Australia, using hydrochemical and isotopic evidence, J. Hydrol., 323, 178-192, 2006.

Bennetts, D. A., Webb, J. A., Stone, D. J. M., and Hill, D. M.: Dryland salinity processes within the discharge zone of a local groundwater system, southeastern Australia, Hydrogeol. J., 15, 1197-1210, 2007.

Benyon, R. G.: Water use by tree plantations in the green triangle, A review of current knowledge, The Glenelg Hopkins Catchment Management Authority, Hamilton, Australia, 2002.

Benyon, R. G., Theiveyanathan, S., and Doody, T. M.: Impacts of tree plantations on groundwater in south-eastern Australia, Aust. J. Bot., 54, 181-192, 2006.

Bormann, M. E.: Temporal and spatial trends in rainwater chemistry across Central and Western Victoria, Honours Thesis, La Trobe University, Melbourne, Australia, 2004.

Bosch, J. M. and Hewlett, J. D.: A review of catchment experiments to determine the effect of vegetation changes on water yield and evapotranspiration, J. Hydrol., 55, 3-23, 1982.

Boutt, D. F., Diggins, P., and Mabee, S.: A field study (Massachusetts, USA) of the factors controlling the depth of groundwater flow systems in crystalline fractured-rock terrain, Hydrogeol. J., 18, 1839-1854, 2010.

Brown, A. E., Zhang, L., McMahon, T. A., Western, A. W., and Vertessy, R. A.: A review of paired catchment studies for determining changes in water yield resulting from alterations in vegetation, J. Hydrol., 310, 28-61, 2005.

Burgess, S. S. O., Adams, M. A., Turner, N. C., White, D. A., and Ong, C. K.: Tree roots: conduits for deep recharge of soil water, Oecologia, 126, 158-165, 2001. 
Butler, J. J., Jin, W., Mohammed, G. A., and Reboulet, E. C.: New insights from well responses to fluctuations in barometric pressure, Ground Water, 49, 525-533, 2011.

Camporese, M., Dean, J. F., Dresel, P. E., Webb, J. A., and Daly, E.: Hydrological modelling of paired catchments with competing land uses, Proceedings of the 20th International Congress on Modelling and Simulation, Adelaide, Australia, 1-6 December 2013, 1819-1825, 2013.

Camporese, M., Daly, E., Dresel, P. E., and Webb, J. A.: Simplified modelling of catchment-scale evapotranspiration via boundary condition switching, Adv. Water Resour., 69, 95-105, 2014.

Cartwright, I., Weaver, T. R., Stone, D., and Reid, M.: Constraining modern and historical recharge from bore hydrographs, ${ }^{3} \mathrm{H}$, ${ }^{14} \mathrm{C}$, and chloride concentrations: Applications to dual-porosity aquifers in dryland salinity areas, Murray Basin, Australia, J. Hydrol., 332, 69-92, 2007.

Cook, P. G.: A Guide to Regional Groundwater Flow in Fractured Rock Aquifers, CSIRO Land and Water, Adelaide, Australia, 2003.

Cook, P. G., Walker, G. R., and Jolly, I. D.: Spatial variability of groundwater recharge in a semiarid region, J. Hydrol., 111, 195212, 1989.

Craddock, J. M.: Methods of comparing annual rainfall records for climatic purposes, Weather, 34, 332-346, 1979.

Cuthbert, M. O.: Straight thinking about groundwater recession, Water Resour. Res., 50, 2407-2424, doi:10.1002/2013WR014060, 2014.

Dalhaus, P. G., Cox, J. W., Simmons, C. T., and Smitt, C. M.: Beyond hydrogeologic evidence: challenging the current assumptions about salinity processes in the Corangamite region, Australia, Hydrogol. J., 16, 1283-1298, 2008.

Dean, J. F., Webb, J. A., Jacobsen, G. E., Chisari, R., and Dresel, P. E.: Biomass uptake and fire as controls on groundwater solute evolution on a southeast Australian granite: aboriginal land management hypothesis, Biogeosciences, 11, 4099-4114, doi:10.5194/bg-11-4099-2014, 2014.

Delin, G. G., Healy, R. W., Landon, M. K., and Bhlke, J. K.: Effects of topography and soil properties on recharge at two sites in an agricultural field, J. Am. Water Resour. As., 36, 1401-1416, 200.

Delin, G. N., Healy, R. W., Lorenz, D. L., and Nimmo, J. R.: Comparison of local- to regional-scale ground-water recharge in Minnesota, USA, J. Hydrol., 334, 231-249, 2007.

Dept. Sustainability and Environment: Groundwater SAFE: Secure allocations, future entitlements, Victorian Gov. Dept. of Sustainability and Environment, Melbourne, Australia, 2012.

Domenico, P. A. and Schwartz, F. W.: Physical and Chemical Hydrogeology, John Wiley and Sons Inc., New York, USA, 528 pp., 1998.

Dresel, P. E., Hekmeijer, P., Dean, J. F., Harvey, W., Webb, J. A., and Cook, P.: Use of laser-scan technology to analyse topography and flow in a weir pool, Hydrol. Earth Syst. Sci., 16, 2703-2708, doi:10.5194/hess-16-2703-2012, 2012.

Edwards, M.: A hydrological, hydrogeological and hydrogeochemical study of processes leading to land and water salinisation in the Mount William Creek catchment, southeastern Australia, $\mathrm{PhD}$ thesis, La Trobe University, Bundoora, Melbourne, Australia, 2006.
Farley, K. A., Jobbágy, E. G., and Jackson, R. B.: Effects of afforestation on water yield: a global synthesis with implication for policy, Glob. Change Biol., 11, 1565-1576, 2005.

Feikema, P. M., Morris, J. D., and Connell, L. D.: The water balance and water sources of a Eucalyptus plantation over shallow saline groundwater, Plant Soil, 332, 429-449, 2010.

Govt. of South Australia: Managing the water resource impacts of plantation forests, Dept. of Water, Land and Biodiversity Conservation, Adelaide, Australia, 2009.

Healy, R. W. and Cook, P. G.: Using groundwater levels to estimate recharge, Hydrogeol. J., 10, 91-109, 2002.

Hekmeijer, P. and Hocking, M.: Feasibility of groundwater pumping from granite slopes, Centre for Land Protection Research, Bendigo, Victoria, Australia, Technical report no. 71, 2001.

Heppner, C. S., Nimmo, J. R., Folmar, G. J., Gburek, W. J., and Risser, D. W.: Multiple-methods investigation of recharge at a humid-region, fractured rock site, Pennsylvania, USA, Hydrogeol. J., 15, 915-927, 2007.

Hergt, J., Woodhead, J., and Schofield, A.: A-type magmatism in the Western Lachlan Fold Belt? A study of granites and rhyolites from the Grampians region, Western Victoria, Lithos, 97, 122139, 2007.

Hibbert, A. R.: Forest treatment effects on water yield, in: International Symposium on Forest Hydrology, edited by: Sopper, W. E. and Lull, H. W., Pergamon, Oxford, UK, 30 August-10 September 1965, 527-543, 1967.

Hutton, J. T. and Leslie, T. I.: Accession of non-nitrogenous ions dissolved in rainwater to soils in Victoria, Aust. J. Agr. Res., 9, 59-84, 1958.

Ierodiaconou, D., Laurenson, L., Leblanc, M., Stagnitti, F., Duff, G., Salzman, S., and Versace, V.: Consequences of land use change on nutrient exports: a regional scale assessment in south-west Victoria, Australia, J. Environ. Management, 74, 305-316, 2005.

Jackson, R. B., Jobbagy, E. G., Avissar, R., Baidya Roy, S., Barrett, D. J., Cook, C. W., Farley, K. A., le Maitre, D. C., McCarl, B. A., and Murray, B. C.: Trading water for carbon with biological carbon sequestration, Science, 310, 1944-1947, 2005.

Jie, Z., van Heyden, J., Bendel, D., and Barthel, R.: Combination of soil-water balance models and water-table fluctuation methods for evaluation and improvement of groundwater recharge calculations, Hydrogeol. J., 19, 1487-1502, 2011.

Jobbagy, E. G. and Jackson, R. B.: Groundwater use and salinization with grassland afforestation, Glob. Change Biol., 10, 12991312, 2004.

Meinzer, O. E.: The occurrence of groundwater in the United States with a discussion of principles, US Geololgical Survey, Washington, D.C., USA, Water-Supply Paper 489, 1923.

Nation, E.: Groundwater Recharge for Agriculture: Rainfall Chemistry Report, Bureau of Rural Sciences, Canberra, Australia, 62 pp., 2009.

Nicholson, C., Dalhaus, P., Anderson, G., Kelliher, C., and Stephens, M.: Corangamite Salinity Action Plan 2005-2008, Corangamite Catchment Management Authority, Colac, Victoria, Australia, 133 pp., 2006.

Rasmussen, T. C. and Crawford, L. A.: Identifying and Removing Barometric Pressure Effects in Confined and Unconfined Aquifers, Ground Water, 35, 502-511, 1997.

Rutledge, A. T.: Computer programs for describing the recession of ground-water discharge and for estimating mean ground-water 
recharge and discharge from streamflow records-update, US Geological Survey, Reston, Virginia, USA, Water-Resources Investigations report 98-4148, 43 pp., 1998.

Scanlon, B. R., Healy, R. W., and Cook, P. G.: Choosing appropriate techniques for quantifying groundwater recharge, Hydrogeol. J., 10, 18-39, 2002.

Scanlon, B. R., Reedy, R. C., Stonestrom, D. A., Prudic, D. E., and Dennehy, K. F.: Impact of land use and land cover change on groundwater recharge and quality in the southwestern US, Glob. Change Biol., 11, 1577-1593, 2005.

Scanlon, B. R., Keese, K. E., Flint, A. L., Flint, L. E., Gaye, C. B., Edmunds, M., and Simmers, I.: Global synthesis of groundwater recharge in semiarid and arid regions, Hydrol. Process., 20, 3335-3370, 2006.

Scanlon, B. R., Jolly, I., Sophocleous, M., and Zhang, L.: Global impacts of conversions from natural to agricultural ecosystems on water resources: Quantity versus quality, Water Resour. Res., 43, W03437, doi:10.1029/2006WR005486, 2007.

Schilling, K. E.: Investigating local variation in groundwater recharge along a topographic gradient, Walnut Creek, Iowa, USA, Hydrogeol. J., 17, 397-407, 2009.

Schofield, N. J.: Tree planting for dryland salinity control in Australia, Agroforest. Syst., 20, 1-23, 1992.

Schrobback, P., Adamson, D., and Quiggin, J.: Turning water into carbon: carbon sequestration and water flow in the MurrayDarling Basin, Environ. Resour. Econ, 49, 23-45, 2011.
Sophocleus, M. A.: Combining the soilwater balanceand waterlevel fluctuation methods to estimate natural groundwater recharge: practical aspects, J. Hydrol., 124, 229-241, 1991.

Toll, N. J. and Rasmussen, T. C.: Removal of barometric pressure effects and earth tides from observed water levels, Ground Water, 45, 101-105, 2007.

van Dijk, A. I. J. M., Hairsine, P. B., Arancibia, J. P., and Dowling, T. I.: Reforestation, water availability and stream salinity: A multi-scale analysis in the Murray-Darling Basin, Australia, Forest Ecol. Manag., 251, 94-109, 2007.

VandenBerg, A. H. M.. Rock unit names in western Victoria, Seamless Geology Project, Geological Survey of Victoria Report, Geoscience, Victoria, Australia, 130, 2009.

Webb, J. A., Williams, B. G., Bailue, K., Walker, J., and Anderson, J. W.: Short-term groundwater dynamics at a paddock scale, Proceedings of Water Down Under Adelaide, Australia, 15-17 April 2008, 1493-1500, 2008.

White, M., Oates, A., Barlow, T., Pelikan, M., Brown, J., Rosengren, N., Cheal, D., Sinclair, S., and Stutter, G.: The Vegetation of North-West Victoria, Department of Sustainability and Environment, Melbourne, Australia, 2003.

Winter, T. C.: The concept of hydrologic landscapes, J. Am. Water Resour. As., 37, 335-349, 2001. 